means of the familiar ionization rule for mixtures of salts with a common ion, viz.: that the degree of ionization of each salt in the mixture is the same as that of a solution of the pure salt at the same ion concentration.

It is shown that large variations in the degrees of ionization (which correspond to different assumptions with regard to the values of the ionic conductances and their change with concentration) produce practically no change in the calculated specific conductances, provided that the conductance of each ion is assumed to depend upon the total equivalent ion concentration. This assumption is identical with stating the equivalent conductance of each salt in a mixture to be equal to the equivalent conductance of a solution of the pure salt at the same ion concentration. The assumption usually made that ionic conductances are constant is included in this more general case.

In the present instance the specific conductances calculated in this way are always greater than the experimental values. The difference is about I.6 per cent. of the actual specific conductance when the concentration of each substance is O.I normal in the mixture, and is less at smaller concentrations. The suggestion is made that the conductance of an ion may depend upon its actual concentration rather than upon the total ion concentration, and it is shown to be possible to obtain a satisfactory agreement between the measured and calculated values by assuming that this is true for hydrogen ion and that hydrochloric acid is ionized to about the same extent as potassium chloride.

The ratio of the specific conductances at $25^{\circ}$ and $18^{\circ}$ has also been determined for 0.01 normal potassium chloride, 0.05 normal hydrochloric acid, and a number of sodium chloride solutions. Déguisne's results are confirmed for the first two solutions, but seem to be about 0.15 per cent. too low in the case of the sodium chloride solutions.

This investigation and the following one were carried out with the aid of a grant made to Professor A. A. Noyes by the Carnegie Institution of Washington. It is desired to express here grateful acknowledgment of this financial aid.

Bовток, March, IgII.

[Contributions From THE RESEarch Laboratory of Physical Chemistry of the MassachusetTs Institute of Technology, No. 68.1

\title{
THE CONDUCTANCE AND IONIZATION OF CERTAIN SALTS AT $18^{\circ}$ AND $25^{\circ}$. \\ BY FRANKLIN L. HENT. \\ Received $\triangle$ pril I, IgII.
}

This investigation is a continuation of earlier work ${ }^{1}$ in this laboratory,

${ }^{1}$ A. A. Noyes, et al., Pub. Car. Inst., 63 (I907); This Jovrnal, 30, 335-53 (1908); A. A. Noyes and J. Johnston, This Journal, 3I, 987, Ioro (I909). 
in which it was shown by means of conductance measurements that the empirical dilution law,

$$
\frac{\text { (Ion concentration) }^{n}}{\text { (Concentration of un-ionized salt) }}=\text { constant, where } n=\text { I.4-I.6, }
$$

holds closely for dilute aqueous solutions of salts of different types over a very wide temperature range. In the present measurements the following substances were investigated at $18^{\circ}$ and $25^{\circ}$ : potassium and barium bromates, silver and thallium sulfates, magnesium nitrate, lead chloride, and sulfuric acid. Measurements were also made at $0^{\circ}$ in the case of sulfuric acid. ${ }^{1}$

The immediate purpose of the investigation was to obtain at $25^{\circ}$ accurate conductance data to assist in interpreting the results of solubility and other investigations in this laboratory. The measurements were also made at $I 8^{\circ}$ in order to enable more definit values to be derived for the conductances of the ions. Absolute values of the latter cannot be determined, since they depend upon $A_{\circ}$ values obtained from conductance measurements by extrapolating to zero concentration, but an effort has been made to obtain values at $18^{\circ}$ and $25^{\circ}$ which are consistent with those derived by Kohlrausch at $18^{\circ}$ from his careful investigations with dilute solutions.

The measurements at $18^{\circ}$ and $25^{\circ}$ were made exactly as described in the preceding article, except that the resistance of the lead wires was only $0.02 \mathrm{ohm}$, instead of 0.05 . The measurements at $0^{\circ}$ were made in a heavily jacketed cylindrical copper vessel of 18 liters capacity containing a mixture of finely cracked ice and water, in which the conductivity vessel was completely submerged. A powerful stirrer was placed near one side of the thermostat and was protected from the ice by a coarsemesh wire gauze. By occasionally adding cracked ice, the temperature was maintained at $0^{\circ}$ within less than $0.01^{\circ}$. The conductance capacities of the cells were assumed the same at $0^{\circ}, 18^{\circ}$ and $25^{\circ}$ and were determined at $18^{\circ}$ by means of 0.0 r normal potassium chloride solutions, usually before and after the measurements on each salt. They were found to remain constant within less than $O . I$ per cent. except during the silver sulfate measurements, where an increase of 0.1 per cent. in the high resistance cell and of 0.35 per cent. in the low resistance cell was detected. Since intermediate values were found when the silver sulfate measurements were about half completed, the conductance capacities were assumed to change at a uniform rate during these measurements.

The substances used (except thallous sulfate and sulfuric acid) were purified by Dr. W. D. Harkins in connection with his work in this laboratory on the effect of salts on the solubility of uni-bivalent salts. Since

1 The results for sulfuric acid solutions have already been interpreted in an article by A. A. Noyes and M. A. Stewart, This Journal, 32, II39 (I9IO). 
the details will soon be published in his article, it is sufficient to state at the present time that special precautions were taken to obtain pure materials. The final crystallization was always made from conductivity water. The silver sulfate was carefully prepared and recrystallized in the dark and remained white on shaking with water. The thallous sulfate was a sample purified by recrystallization by Dr. K. G. Falk, ${ }^{1}$ of this laboratory. The sulfuric acid was taken from a fresh bottle of Baker and Adamson's "strictly chemically pure" acid, another bottle of which had formerly been carefully tested by Mr. Y. Kato in this laboratory. ${ }^{2}$

A stock solution of each substance was prepared, and from it by dilution was derived a complete series of solutions whcse concentrations corresponded very closely to the round concentrations given in the tables below. The results obtained with these solutions were checked by independent measurements, as shown in the tables. In the case of silver sulfate and magnesium nitrate a second stock solution was made up from a second sample of salt prepared by a different method. In the second series of measurements with thallous sulfate and the third with silver sulfate the separate solutions were prepared by weighing out the proper amount of the solid salt. The thallous sulfate was dried at $150-160^{\circ}$, and the silver sulfate at about $100^{\circ}$. The latter salt darkened slightly on heating at this temperature, but no corresponding change in the conductance of the solutions was detected. The check measurements with sulfuric acid were made with two sets of solutions derived from the original stock solution.

These check measurements agreed within o.1 per cent., except in three instances, $0.2 \mathrm{NTl}_{2} \mathrm{SO}_{4}, 0.002 \mathrm{~N} \mathrm{Mg}\left(\mathrm{NO}_{3}\right)_{2}$ and $0.01 \mathrm{~N} \mathrm{H}_{2} \mathrm{SO}_{4}$, where the two values differed by less than 0.2 per cent., and in the dilute silver sulfate solutions, where the results were less satisfactory than in the other cases, doubtless on account of the uncertainty intraduced by the variation of the conductance capacity of the low resistance cell. Here the extreme variations were less than 0.3 per cent. in the most dilute solution and less than 0.2 per cent. in the other cases. In the case of thallous sulfate, to test for a possible change of conductance on standing, an approximately 0.02 normal solution was prepared, transferred at once to the conductivity vessel, and measured at intervals of five minutes for an hour and a half. No appreciable change was detected in this case, nor in other dilute solutions on standing several days. Since these measurements were made, Mr. Winninghoff has found in three separate o. I $N$ solutions a small increase of conductance on standing of not more than 0.2 per cent. His values after 2 to 4 days agreed within less than o.I per cent. with that (96.0) given in Table III below. The conductances of the saturated

1 This Journal, 32, I557 (1910).

2 A. A. Noyes, Pub. Car. Inst., 63, 242 (1907). 
solutions of silver sulfate, barium bromate, and lead chloride at $25^{\circ}$ were also measured and, as will be shown below, furnish checks for the results obtained in the more concentrated solutions of the regular series. Check measurements in the case of potassium bromate seemed unnecessary, since no serious irregularities were found in the other cases.

Measurements were also made with supersaturated solutions of silver sulfate at $25^{\circ}$. Solutions nearly saturated at $50^{\circ}$ and $70^{\circ}$ were prepared free from crystals, and cooled to $25^{\circ}$. After the removal of portions for analysis, the solutions were carefully transferred to the conductivity cell, and measurements were made as quickly as possible. The conductance usually remained constant for a few minutes, and then began to decrease steadily. This decrease was undoubtedly due to crystallization on the electrodes, since after the measurements a fine deposit of crystals was generally abserved on the electrodes. The initial values obtained in five experiments are included in Table III below.

The most concentrated solutions of thallous sulfate ( 0.2 normal) and of barium bromate $\left(0.04\right.$ normal) were slightly supersaturated at $18^{\circ}$, and crystallization on the electrodes sometimes took place. There was no difficulty, however, in obtaining reproducible values.

Scme of the solutions of thallous sulfate and magnesium nitrate were shown to be neutral by means of indicators. ${ }^{1}$ They reacted alkaline towards litmus and acid to rosolic acid, thus proving that the concentration of bydrogen ion was approximately $1 \mathrm{IO}^{-7}$.

The concentrations of the saturated, supersaturated, and stock solutions were determined by direct analysis. Except in the case of thallous sulfate and of sulfuric acid the analyses were made by Dr. W. D. Harkins by methods which will be described in detail in his article. The silver sulfate and lead chloride solutions were analyzed by weighing silver shloride. The two stock solutions of the silver sulfate had been prepared by weighing out salt from which the water had been almost completely removed in a vacuum desiccator at room temperature; the concentrations calculated from these weights differed by 0.1 and 0.2 per cent. from the analytically determined values. The barium and potassium bromate solutions were analyzed by reducing the bromate with hydrazine, and weighing silver bromide. The concentrations of the two magnesium nitrate stock solutions were determined by evaporating known weights of the solutions with sulfuric acid on a water bath, heating, and weighing the magnesium sulfate. The thallous sulfate solutions were prepared by weighing directly salt which had been dried at $150-160^{\circ}$. A single analysis of the stock solution, made by Dr. K. G. Falk, in which the thallium was weighed as iodide, ${ }^{2}$ gave a concentration only 0.07 per cent. less than the accepted

${ }^{1}$ Salm, Z. physik. Chem., 57, 47 I (I906).

${ }^{2}$ K. G. Falk, This JournaL, 32, i560 (IgIo). 
value. The stock sulfuric acid solution was analyzed by titrating weighed portions (with phenolphthalein as indicator) against carbon dioxide-free alkali, which had been standardized by means of the standard hydrochloric acid solution described in the preceding article.

Concentrations are expressed in equivalents per liter, based on the international atomic weights for igro. Two-gram equivalents of each of the uni-bivalent salts, including barium bromate, are of course equal to one gram molecule. In the tables given below concentrations are expressed, for convenience, as millimols per liter, $1000 \mathrm{C}$, at the temperatures in question. During the investigation all dilutions were made at $25^{\circ}$ with flasks calibrated at $25^{\circ}$, and concentrations were therefore expressed as mols per liter at this temperature. The concentrations at other temperatures were computed by assuming the temperature coefficient of contraction to be the same as that of water, except in the case of 0.2 normal sulfuric acid. The concentration of this solution at $0^{\circ}$ was assumed to be 0.37 per cent. ${ }^{1}$ greater than at $25^{\circ}$, instead of 0.28 per cent. as in the other cases.

In the tables round concentrations are given instead of the actual ones. The equivalent conductances $(A)$ were derived from the values at the actual concentrations by applying a small correction based on the rate at which $A$ changes with $\mathrm{C}$ at that particular concentration, as derived from the plots described in the following paragraph. The round concentrations differed from the actual by about 3 per cent. in the case of barium bromate, by only 0.4 to 0.8 per cent. in the case of lead chloride, and by even smaller amounts in the remaining cases.

It is easily shown ${ }^{2}$ that when the empirical dilution law given in the first lines of this article holds over a definit range of concentration for some value of $n$, a straight-line plot must be obtained in the same range on plotting $\mathrm{I} / A$ against $(\mathrm{C} A)^{n-1}$. Conversely, by plotting the results for several values of $n$, that value which gives the best straight line in a given concentration range may be chosen. In order to compare the curvature of the various lines more easily the values of $(\mathrm{C} A)^{n-1}$ for each $n$ are usually multiplied by a factor such that all the lines pass through a point corresponding to a concentration of say 0.1 equivalent per liter. This method of plotting has proved of great value in interpolating values of $A$ at different concentrations, and has also been used in extrapolating to zero concentration to obtain $A_{\circ}$ values. In the latter case, however, the results are not very definit, since the values of $n$ to use in extrapolating cannot be accurately determined.

The present results were plotted in this way, and the plots for each salt

${ }^{1}$ Landolt-Börnstein-Meyerhoffer, Tabellen, 326.

${ }^{2}$ A. A. Noyes, Pub. Car. Inst., 63, 50, 334; cf. also This Journal, 3 I, 745, 994, 996, IOIO. 
were found to be almost exactly similar at $18^{\circ}$ and $25^{\circ}$. Smooth curves were obtained in each case, thus showing that the results at the different concentrations are concordant, probably within o.I per cent. The data for the saturated solutions of silver sulfate, barium bromate, and lead chloride at $25^{\circ}$ were perfectly concordant with the results at lower concentrations, since the curves obtained at lower concentrations, when produced, passed through the points corresponding to the saturated solutions. The two sets of values are completely independent, and this result therefore furnishes a proof of the accuracy of the conductance measurements. The values for three of the supersaturated solutions of silver sulfate were also concordant with these results, but the two other values (at 0.07 I 8 normal) were not, and were therefore rejected.

By means of these $\mathrm{I} / A,(\mathrm{C} A)^{n-1}$ curves it was easy to choose with an accuracy of about \pm 0.03 the value of $n$ which gave the best straight line over any given range of concentration. In almost every case there was distinct evidence that the "best" values of $n$ increased with decreasing concentration. ${ }^{1}$ Probable values of $\Lambda_{0}$ for each salt were accordingly calculated at $18^{\circ}$ and $25^{\circ}$ by choosing the best value of $n$ in dilute solutions. These preliminary values were then compared by Dr. K. G. Falk and Dr. W. C. Bray with similar values for other salts at these temperatures, and a concordant series of ionic conductances was finally adopted by them based chiefly on the results of Kohlrausch and his assistants at $18^{\circ}$. The resulting values of $A_{0}$ for the salts investigated by me are given in the following table, together with the values of $n$ which enable these values of $A_{\circ}$ to be obtained by extrapolation $\left(n_{0}\right)$, and approximate values of $n$ between the concentrations 0.02 and 0.1 normal $\left(n_{0,02-0,10}\right)$.

\begin{tabular}{|c|c|c|c|}
\hline$\Lambda_{0}$ at $1^{\circ}$. & $\Delta$ at $25^{\circ}$. & $n_{0}$. & $n_{0.02-0.20}$ \\
\hline I I 2. I & 129.6 & I. 53 & I. 45 \\
\hline 107.7 & 125.6 & I. 45 & I. 35 \\
\hline 103.0 & I 20.0 & I. 50 & I.45 \\
\hline 122.5 & I 43.4 & I. $5^{8}$ & I. 50 \\
\hline I 34.4 & I56.0 & I. $5^{8}$ & 1.50 \\
\hline 126.3 & I 47.0 & 1.65 & I. 70 \\
\hline
\end{tabular}

The "probable" $A_{\circ}$ values derived for the separate salts agreed very well with the final values except in the case of lead chloride. Here the first values (based on the exponent $n_{\circ}=1.70$ ) were about one unit less than those adopted as a result of a comparison with the data of Kohlrausch and Grüneisen for lead nitrate and potassium chloride at $18^{\circ}$. It is by no means certain that the larger values are more nearly correct, but they have been adopted for the sake of uniformity with the other results at $18^{\circ}$. It is not improbable, moreover, that our present $A_{\circ}$ values are ${ }^{2}$ Cf. This Journal, 3I, 746, IOII. 
all too high, especially in the case of polyvalent salts, since the exponent $n$ may continue to increase in very dilute solutions, instead of remaining constant as assumed in the extrapolation.

In this table the uni-bivalent salts are arranged in the order of the increasing values of $n_{0}$. A comparison with the values of the degrees of ionization given below shows that at any concentration the degrees of ionization decrease in the same order. It is interesting to note that in the case of lead chloride the value of $n$ is usually high throughout and that this salt is less ionized than the other uni-bivalent salts.

The values adopted for the equivalent conductances of the ions are given in the following table:

TABLE II.-EQUIVALENT CONDUCtances OF THE IONS.

$\begin{array}{lccccc}\text { Cation. } & \Lambda_{18 .} & \Lambda_{25} . & A_{\text {nion. }} & \Lambda_{18 .} & \Lambda_{25 .} \\ \mathrm{K}^{+} \ldots \ldots \ldots \ldots & 64.5 & 74.8 & \mathrm{BrO}_{3} & 47.6 & 54.8 \\ \mathrm{Ag}^{+} \ldots \ldots \ldots \ldots & 54.0 & 63.4 & \mathrm{NO}_{2} & 61.8 & 70.6 \\ \mathrm{I} / 2 \mathrm{M} \mathrm{g}^{++} \ldots \ldots \ldots & 45.9 & 55.0 & \mathrm{Cl} & 65.5 & 75.8 \\ \mathrm{I} / 2 \mathrm{Ba}^{++} \ldots \ldots \ldots & 55.4 & 65.2 & \mathrm{I} / 2 \mathrm{SO}_{4} & 68.5 & 80.0 \\ \mathrm{I} / 2 \mathrm{~Pb}^{++} \ldots \ldots \ldots & 60.8 & 71.2 & \ldots & \ldots & \ldots \\ \mathrm{I} / 2 \mathrm{~T} 1^{++} \ldots \ldots \ldots & 65.9 & 76.0 & \ldots & \ldots & \ldots\end{array}$

In Table III the values of equivalent conductance $(A)$ at different concentrations ( $1000 \mathrm{C}$ ) are given. Saturated solutions are designated by the letter (s), supersaturated by (ss). The value for the saturated solution of barium bromate was determined by Dr. W. D. Harkins. The conductance of the o.I normal $\mathrm{H}_{2} \mathrm{SO}_{4}$ solution was also measured at $18^{\circ}$ and found to be 233.2. This agrees within 0.05 per cent. with the result given by Eastman ${ }^{1}$ and is 3.6 per cent. greater than that given by Kohlrausch. ${ }^{2}$

The percentage ionizations of the salts ( $100 \gamma=100 \mathrm{~A} / A_{\mathrm{o}}$ ) are given in Table IV. The degree of ionization of each salt at $25^{\circ}$ is seen to be

Table III.-Conductance Data.

\begin{tabular}{|c|c|c|c|c|c|c|c|c|}
\hline \multirow{2}{*}{$\begin{array}{l}\text { Conc. } \\
\text { at } t^{\circ} \text {. }\end{array}$} & \multicolumn{2}{|c|}{$\mathrm{Tl}_{2} \mathrm{SO}_{4}}$. & \multicolumn{2}{|c|}{$\mathrm{Mg}\left(\mathrm{NO}_{3}\right)_{2}$} & \multicolumn{2}{|c|}{$\mathrm{KBrO}_{3}}$. & \multicolumn{2}{|c|}{$\mathrm{H}_{2} \mathrm{SO}_{4}$. } \\
\hline & $18^{\circ}$. & $25^{\circ}$. & $18^{\circ}$. & $25^{\circ}$. & $18^{\circ}$. & $25^{\circ}$. & $\infty^{\infty}$ & $25^{\circ}$. \\
\hline $0 \ldots \ldots \ldots$ & 134.4 & I 56.0 & 107.7 & 125.6 & II $2 . I$ & 129.6 & . . & .. \\
\hline I. ........ & I $27 \cdot 35^{*}$ & $147.8 *$ & $120.6 *$ & $19.5^{*}$ & .9 & 126.9 & 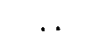 & . \\
\hline $2 \ldots \ldots \ldots$ & $124.2 *$ & I $44.2^{*}$ & $100.8^{*}$ & $17.4^{*}$ & 8.7 & 125.6 & $\cdots$ & $\cdots$ \\
\hline $5 \ldots \ldots \ldots$ & II $8.4^{*}$ & $137 \cdot 3^{*}$ & $97 \cdot 7^{*}$ & $\operatorname{II} 3 \cdot 7^{*}$ & 5.9 & 123.4 & . & .. \\
\hline Io........ & I $2.3^{*}$ & I $30.0 *$ & $94.65^{*}$ & I $10.05^{*}$ & 4.7 & 121.0 & $226.4^{*}$ & $336.8^{*}$ \\
\hline $20 \ldots \ldots \ldots$ & 104.55 & 120.9 & 90.9 & $105 \cdot 7$ & 102.0 & I 17.8 & $\ldots$ & . \\
\hline $25 \ldots \ldots \ldots$ & 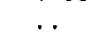 & $\ldots$ & .. & . . & . . & 116.6 & 206.95 & $299 \cdot 3$ \\
\hline $50 \ldots \ldots$ & $92 \cdot 7^{*}$ & ro7. I* & $85 \cdot 3$ & 99.0 & $97 \cdot 3$ & 112.4 & IgI. 5 & 273.1 \\
\hline 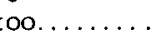 & 83.1 & 96.0 & $80.5^{*}$ & $93 \cdot 4^{*}$ & 93.0 & 107.2 & I $77.2^{*}$ & $251.2^{*}$ \\
\hline o......... & $73.8^{*}$ & $85.0 *$ & $75 \cdot 3$ & 87.2 & 87.8 & rOI. I & $\mathrm{I} 65.4$ & 234.7 \\
\hline
\end{tabular}

${ }^{1}$ A. A. Noyes, et al, Pub. Car. Inst., 63, 262 (I907).

${ }^{2}$ Landolt-Börnstein-Meyerhoffer, Tabellen, 746.

* Mean of two values. 
TABLE III (Continued).

\begin{tabular}{|c|c|c|c|c|c|c|}
\hline \multirow{2}{*}{$\begin{array}{l}\text { Conc. } \\
\text { at } t^{\circ} \text {. }\end{array}$} & \multicolumn{2}{|c|}{$\mathrm{Ag}_{2} \mathrm{SO}_{4}}$. & \multicolumn{2}{|c|}{$\mathrm{Ba}\left(\mathrm{BrO}_{3}\right)_{2}$} & \multicolumn{2}{|c|}{$\mathrm{PbCl}_{2}$. } \\
\hline & $18^{\circ}$ & $25^{\circ}$ & $18^{\circ}$ & $25^{\circ}$ & $18^{\circ}$. & $25^{\circ}$ \\
\hline$o \ldots \ldots \ldots \ldots \ldots$ & 122.5 & 143.4 & 103.0 & 120.0 & 126.3 & 147.0 \\
\hline $\mathbf{I}, \ldots \ldots \ldots \ldots$ & $116.3 \dagger$ & $135.7 \dagger$ & $97 \cdot 5$ & $1 \mathrm{I} 3.6$ & IIg. I 5 & $\mathrm{I} 38.7$ \\
\hline $2 \ldots \ldots \ldots \ldots \ldots$ & $113.6 \dagger$ & $132.6 \dagger$ & $95 \cdot 5$ & I I I . 2 & 115.8 & $\mathrm{I} 34 \cdot 5$ \\
\hline $4 \ldots \ldots \ldots \ldots \ldots$ & 109.85 & 128.0 & . & $\ldots$ & $\ldots$ & . \\
\hline $5 \ldots \ldots \ldots \ldots \ldots$ & $108.4 \dagger$ & $126.3 \dagger$ & 91.9 & 106.95 & 109.2 & I 26.8 \\
\hline го............... & $102.9 \dagger$ & II9.9† & 88.2 & $102 \cdot 7$ & $102 . I$ & II 8.2 \\
\hline $20 \ldots \ldots \ldots \ldots \ldots$ & $96 . \mathrm{I} *$ & $\operatorname{IIt} \cdot 7^{*}$ & 83.6 & $97 \cdot 3$ & 93.2 & 107.6 \\
\hline $40 \ldots \ldots \ldots \ldots \ldots$ & $88.0 *$ & $\mathrm{IO} .2^{*}$ & $78 \cdot 3$ & $9 \mathrm{I} \cdot \mathrm{I}$ & . & $\cdots$ \\
\hline $40.2(s) \ldots \ldots \ldots \ldots$ & . & . & . & 9I.I & . & . \\
\hline $50 \ldots \ldots \ldots \ldots \ldots$ & . & $97 \cdot 7 \dagger$ & . & $\cdots$ & 79.2 & $91 \cdot 3$ \\
\hline $53.74(s) \ldots \ldots \ldots \ldots$ & . & $94 \cdot 3^{*}$ & $\cdots$ & $\cdots$ & . & . \\
\hline $7 \mathrm{I} .8(\mathrm{ss}) \ldots \ldots \ldots \ldots$ & $\cdots$ & $93 \cdot 5$ & . & . & . & . \\
\hline $72.0(\mathrm{ss}) \ldots \ldots \ldots \ldots$ & . & $92.15^{*}$ & . & . & . & . \\
\hline $78.2(s s) \ldots \ldots \ldots \ldots$ & . & .. & . & . & $\ldots$ & $\ldots$ \\
\hline $77.54(s) \ldots \ldots \ldots \ldots$ & . & .. & . & . & . & $82.6^{*}$ \\
\hline
\end{tabular}

somewhat less than at $18^{\circ}$, but the difference decreases with decreasing concentration, and is in general almost negligible in very dilute solutions. It is of interest to note that $\gamma$ is practically the same for magnesium nitrate

TAble IV.-Percentage Ionization of the Salts.

\begin{tabular}{|c|c|c|c|c|c|c|}
\hline \multirow{2}{*}{$\begin{array}{l}\text { Concentration } \\
\text { at } t^{\circ} \text {. }\end{array}$} & \multicolumn{2}{|c|}{$\mathrm{Tl}_{2} \mathrm{SO}_{4}$} & \multicolumn{2}{|c|}{$\mathrm{Mg}\left(\mathrm{NO}_{3}\right)_{2}$} & \multicolumn{2}{|c|}{$\mathrm{KBrO}_{3}}$. \\
\hline & $18^{\circ}$. & $25^{\circ}$ & $18^{\circ}$ & $25^{\circ}$ & $18^{\circ}$. & $25^{\circ}$ \\
\hline${ }_{1} \ldots \ldots \ldots \ldots \ldots \ldots$ & 100 & 100 & 100 & 100 & 100 & 100 \\
\hline $1 \ldots \ldots \ldots \ldots \ldots \ldots$ & $94 \cdot 7$ & $94 \cdot 7$ & $95 \cdot 3$ & 95.2 & 98.0 & $97 \cdot 9$ \\
\hline $2 \ldots \ldots \ldots \ldots \ldots \ldots, \ldots$ & 92.4 & 92.4 & 93.6 & $93 \cdot 5$ & 97.0 & 96.9 \\
\hline $5, \ldots \ldots \ldots \ldots \ldots \ldots, \ldots$ & $88 . \mathrm{I}$ & 88.0 & 90.7 & 90.5 & $95 \cdot 3$ & 95.2 \\
\hline 10. $\ldots \ldots \ldots \ldots \ldots \ldots \ldots \ldots \ldots$ & $83 \cdot 5$ & 83.4 & $87 \cdot 9$ & 87.6 & $93 \cdot 4$ & 93.4 \\
\hline $20, \ldots \ldots \ldots \ldots \ldots \ldots \ldots$ & 77.8 & $77 \cdot 5$ & $84 \cdot 4$ & $84 \cdot x$ & $9 \mathrm{r} . \mathrm{O}$ & 90.9 \\
\hline $50 \ldots \ldots \ldots \ldots \ldots \ldots \ldots$ & 69.0 & 68.7 & 79.2 & 78.8 & 86.8 & 86.7 \\
\hline IоO. $\ldots \ldots \ldots \ldots \ldots \ldots$ & 61.9 & $6 r \cdot 5$ & 74.8 & $74 \cdot 4$ & 82.9 & 82.7 \\
\hline $200 \ldots \ldots \ldots \ldots \ldots \ldots \ldots$ & 54.9 & $54 \cdot 5$ & 69.9 & $69 \cdot 4$ & 78.3 & 78.0 \\
\hline \multirow{2}{*}{$\begin{array}{l}\text { Concentration } \\
\text { at } t^{\circ} \text {. }\end{array}$} & \multicolumn{2}{|c|}{$\mathrm{Ag}_{2} \varsigma \mathrm{O}_{4}$} & \multicolumn{2}{|c|}{$\mathrm{Ba}\left(\mathrm{BrO}_{3}\right)_{2}$} & \multicolumn{2}{|c|}{$\mathrm{PbCl}_{2}$. } \\
\hline & I $8^{\circ}$. & $25^{\circ}$ & $18^{\circ}$ & $25^{\circ}$ & $18^{\circ}$. & $25^{\circ}$ \\
\hline o. $\ldots \ldots \ldots \ldots \ldots \ldots \ldots \ldots$ & 100 & IOO & 100 & 100 & 100 & 100 \\
\hline I $\ldots \ldots \ldots \ldots \ldots \ldots \ldots$ & 95.0 & $94 \cdot 7$ & $94 \cdot 7$ & $94 \cdot 7$ & $94 \cdot 3$ & $94 \cdot 3$ \\
\hline $2 \ldots \ldots \ldots \ldots \ldots \ldots, \ldots$, & $92 \cdot 7$ & $92 \cdot 5$ & $92 \cdot 7$ & $92 \cdot 7$ & $9 \mathrm{I} \cdot 7$ & $91 \cdot 5$ \\
\hline $4 \ldots \ldots \ldots \ldots, \ldots, \cdots \cdots$ & 89.5 & $89 \cdot 3$ & $\cdots$ & . & $\cdots$ & $\cdots$ \\
\hline $5 \ldots \ldots \ldots \ldots \ldots \ldots \ldots$ & 88.5 & 88.1 & 89.2 & 89.2 & 86.5 & 86.3 \\
\hline Io. $\ldots \ldots \ldots \ldots \ldots \ldots \ldots$ & 84.0 & 83.6 & $85 \cdot 7$ & 85.6 & 80.8 & 80.4 \\
\hline $20 \ldots \ldots \ldots \ldots \ldots \ldots \ldots$ & 78.4 & $77 \cdot 9$ & 81.2 & $8 \mathrm{I} \cdot \mathrm{I}$ & 73.8 & 73.2 \\
\hline $40 \ldots \ldots \ldots \ldots \ldots \ldots \ldots$ & 71.8 & $71 \cdot 3$ & 76.0 & $75 \cdot 9$ & . & $\cdots$ \\
\hline $50 \ldots \ldots \ldots \ldots \ldots \ldots \ldots$ & . & $\therefore$ & $\cdots$ & $\cdots$ & $62 \cdot 7$ & 62.1 \\
\hline $53.74 \ldots \ldots \ldots \ldots \ldots \ldots \ldots$ & . & 68.1 & - & . & . & . \\
\hline $78.2 \ldots \ldots \ldots \ldots \ldots \ldots \ldots$ & . & $64 \cdot 3$ & . & . & . & $\cdots$ \\
\hline $\begin{array}{l}77 \cdot 54 \ldots \ldots \ldots \ldots \ldots \\
\quad * \text { Mean of two values. } \\
\text { †Mean of three values. }\end{array}$ & $\cdots$ & . & $\cdots$ & . & . & 56.2 \\
\hline
\end{tabular}


and magnesium chloride, and for potassium bromate and potassium nitrate. It is slightly less for barium bromate than for barium nitrate, and for thallous sulfate than for silver sulfate. Thallous and silver sulfates are somewhat less ionized than lead nitrate, and all three are much less ionized than nearly all other uni-bivalent salts. In fact below 0.05 normal their degrees of ionization are less than for the two uni-trivalent salts, lanthanum nitrate and potassium citrate, investigated by Noyes and Johnston. ${ }^{1}$ The ionization is even less in the case of lead chloride and is still less in the case of cadmium chloride. It is evident that a number of salts ${ }^{2}$ such as those of silver, thallium, lead and cadmium, are less ionized than typical salts of the same valence product type ${ }^{3}$ and thus occupy an intermediate position between typical strong electrolytes, and weak electrolytes, such as mercuric chloride.

In conclusion the author wishes to express his indebtedness to Professor A. A. Noyes and Professor W. C. Bray, of this laboratory, for assistance in connection with the experimental work and the preparation of this article for publication.

Boston, March, igII.

\section{CONTRIBUTIONS TO THE ELECTROCHEMISTRY OF HYDRO- NITRIC ACID AND ITS SALTS. I. THE CORROSION OF SOME METALS IN SODIUM TRINITRIDE SOLUTION.}

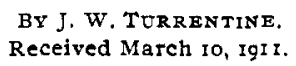

Introduction.

While hydronitric acid has received its full quota of attention from investigators in both inorganic and organic chemistry, and a large mass of experimental data concerning this interesting new addition to the family of inorganic acids has been accumulated, its study from the electrochemical point of attack has been for the most part neglected.

It is the purpose of the research, one chapter of which is here reported, to investigate the behavior of the nitride ion ( $\mathrm{I}$ ) on being discharged against a soluble anode; (2) on being discharged against an insoluble anode; (3) on being acted upon in the anode region by discharged anions, or anode products (electrochemical oxidation); and (4) on being acted upon in the cathode region by discharged cations, or cathode products (electrochemical reduction). Also, the determination of some of the electrochemical constants of hydronitric acid and its compounds is anticipated. In all of this work special attention will be paid to a comparison of the behavior of the nitride ion with that of other ions, in order that its true position in the family of anions may be shown.

I This Journal, 3i, IOO2 (IgO9).

2 Cf. Abbott and Bray, This Journal, 3r, 753 (IgOg).

${ }^{3}$ Noyes and Johnston, Loc. cit., 1003. 